\title{
Avaliando vínculos entre partidos e deputados nas Assembleias Legislativas brasileiras
}

Carlos Ranulfo Melo

\section{I ntrodução}

Este artigo analisa a relação entre deputados e partidos em Assembleias Legislativas no Brasil e replica o modelo utilizado em estudo anterior (Melo, 2011) feito a partir de material empírico recolhido em 12 estados brasileiros: Rio Grande do Sul, Santa Catarina, São Paulo, Rio de Janeiro, Minas Gerais, Bahia, Pernambuco, Ceará, Pará, Tocantins, Goiás e Mato Grosso. A base de dados pertence ao projeto "Trajetórias, perfis e padrões de interação de legisladores estaduais em 12 unidades da Federação", conduzido por pesquisadores do Centro de Estudos Legislativos do DCP/UFMG. Os dados cobrem duas legislaturas: as de 2007-2011 e 2011-2015. Na primeira legislatura foram entrevistados 513 deputados ( $82,3 \%$ de um universo de 624 legisladores). Na segunda o número de entrevistas foi de $439(70,7 \% \text { do universo })^{1}$.

O ponto de partida para a análise é a opinião dos legisladores entrevistados. $\mathrm{O}$ objetivo do artigo é explicar a variação encontrada quando se analisa o perfil, mais ou menos partidário, dos deputados. A primeira hipótese a ser verificada é a de que os deputados apresentarão perfil mais nitidamente partidário naqueles estados onde a competição eleitoral se mostrar mais estável. A estabilidade é avaliada com base nos resultados eleitorais para as Assembleias, as bancadas estaduais da Câmara dos Deputados e os governos, além de levar em conta o percentual de troca de partidos realizada no nível federal. A hipótese parte da noção de que os 27 subsistemas partidários brasileiros apresentam grande variação, tanto no que se refere aos partidos relevantes como no que tange ao padrão de interação estabelecido (quando existe) entre eles.

A segunda linha de explicação remete às características dos deputados eleitos. A partir dos dados recolhidos nos surveys foram testadas as hipóteses de que os deputados apresentarão perfil mais partidário quando: a) estiverem filiados a seus

\footnotetext{
${ }^{1} \mathrm{O}$ autor agradece aos demais pesquisadores envolvidos no projeto - Fátima Anastasia, Magna Inácio, Mônica Mata Machado de Castro e Manoel Leonardo Santos - além das dezenas de estudantes de graduação e pós-graduação que auxiliaram no desenvolvimento da pesquisa. O projeto "Trajetórias" conta, desde 2007, com financiamento do CNPq e da Fapemig.
} 
partidos há mais tempo; b) se perfilarem à esquerda; c) apresentarem menor tendência a um mandato de tipo particularista; d) se posicionarem de forma progressista relativamente a temas como redução da maioridade penal, união civil de homossexuais, descriminalização de drogas, pena de morte, proibição do uso de armas e aborto; e) não pertencerem a uma igreja evangélica; f) não pertencerem a famílias com tradição política; e g) possuírem menor renda.

Este artigo contém quatro seções, além desta Introdução e da Conclusão. Na próxima seção, "Calculando o índice de partidarismo", depois de breve discussão acerca da relação entre deputados e partidos no Brasil, é apresentada a variável dependente do estudo, o índice de partidarismo, que permite classificar os deputados com base na importância conferida aos partidos políticos. O texto explica como se chegou ao índice e mostra sua variação. A terceira seção, "Estabilidade da competição eleitoral e sistemas partidários estaduais", é dedicada aos sistemas partidários nos estados estudados. A partir de um conjunto de indicadores chega-se a um índice que permite classificar os 12 subsistemas partidários de acordo com uma das dimensões da institucionalização - a estabilidade da competição eleitoral. Na seção seguinte, "Mudando o nível de análise: o que caracteriza os deputados partidários?", são apresentadas as hipóteses que buscam vincular determinadas características dos deputados à sua posição no índice de partidarismo. A quinta seção, "Testando as hipóteses", apresenta o modelo de regressão com o conjunto das variáveis independentes indicadas e discute os resultados.

\section{Calculando o índice de partidarismo}

É comum que os partidos brasileiros sejam tratados como organizações frágeis, pouco coesos e altamente descentralizados, nos quais os políticos seriam dotados de ampla liberdade de ação e as seções estaduais e locais contariam com elevada autonomia decisória. As razões para tanto estariam na estrutura institucional adotada no país, em especial, a combinação do federalismo com o sistema eleitoral de lista aberta, que retiraria dos partidos, e principalmente das direções nacionais, a possibilidade de controle sobre decisões cruciais para as carreiras políticas individuais (Samuels, 1997; Mainwaring, 1991, 1999; Ames, 2001). Nesse sentido, o Brasil seria um caso em que proliferam os políticos "sem partido".

Tal diagnóstico, no entanto, corresponde apenas em parte à realidade. Sabe-se que os partidos brasileiros possuem controle sobre considerável volume de recursos de poder, o que remete a uma das condições básicas para a robustez de qualquer organização. No Legislativo nacional, os partidos situam-se em posição estratégica para o processamento das decisões legislativas, sejam aquelas que interessam ao poder Executivo ou as que estão na lista de prioridade dos deputados - quanto a este último 
aspecto, a reformulação dos Regimentos Internos da Câmara e do Senado, realizada em 1989, concentrou recursos nas mãos dos líderes de bancada, concedendo-lhes poder de agenda e reduzindo a capacidade de barganha dos legisladores individualmente (Figueiredo e Limongi, 1999, 2002; Santos, 2003). Ainda que parcialmente, tal quadro repete-se nas Assembleias, onde na maioria das vezes a elaboração dos regimentos internos tomou como base o caso nacional. Os partidos controlam, ainda, o acesso às inserções no rádio e na TV - seja nos anos eleitorais ou entre as eleições - e os recursos do Fundo Partidário, que a partir de 1995 passaram a ser muito expressivos. Finalmente, desde 2007, com a decisão do TSE, os partidos têm a possibilidade de, se assim o desejarem, reivindicar o mandato daqueles que decidam abandonar a sigla pela qual foram eleitos.

Ademais, é preciso levar em conta que, no que se refere ao atual sistema partidário, são escassas as pesquisas que tomam os partidos como unidades de análise. Exceção feita ao PT, que por ser tratado como uma "anomalia" foi alvo de vários estudos (Meneguello, 1989; Keck, 1991; Samuels, 2004, 2008; Hunter, 2007, 2010; Ângelo e Villa, 2009; Amaral, 2010, 2011; Ribeiro, 2010; Singer, 2009, 2010; Venturi, 2010), os demais partidos apenas ocasionalmente foram analisados com alguma atenção pela literatura (Ferreira, 2002; Roma, 2002; Tarouco, 2002; Almeida, 2004; Ribeiro, 2011; Vieira, 2012). A falta de embasamento empírico faz com que pouco se saiba a respeito de como se realizam os jogos de poder partidários, até que ponto as lideranças controlam ou não a tomada de decisões e em que contextos os partidos assumem importância para a carreira de seus membros.

Mais recentemente, no entanto, alguns autores vêm analisando de forma comparada a estrutura organizacional dos principais partidos nacionais e têm chegado a conclusões que problematizam a noção de organizações nas quais as direções nacionais seriam atores dotados de poucos recursos diante do desejo de autonomia de seus membros individuais. Como mostra Ribeiro (2013), partidos como o PSDB e o DEM adotaram medidas no sentido de promover maiores graus de centralização e articulação interna de suas agremiações. Guarnieri (2011), por sua vez, mostra que a organização adotada pelos partidos incide sobre a decisão de lançar ou não candidatos a cargos majoritários nos estados e municípios.

Uma análise mais acurada indica que o Brasil comporta, e continuará comportando, um arranjo institucional ambivalente no que se refere à relação entre os deputados e seus partidos. De um lado, fortes incentivos à priorização das reputações pessoais ante as partidárias (Carey e Shugart, 1995) levam à adoção, por parte dos candidatos, de estratégias capazes de diferenciá-los dos demais competidores, inclusive os de seu partido, e, ao mesmo tempo, consolidar os seus laços com os eleitores. De outro, a percepção de que os partidos brasileiros de fato controlam recursos de monta 
faz com que valha a pena investir na construção de uma reputação coletiva, independentemente da existência de orientações normativas a respeito do papel dos primeiros na democracia.

Dessa forma, trajetórias políticas nas quais as diversas legendas disponíveis no mercado eleitoral são utilizadas de forma contingente continuarão a conviver com aquelas para as quais o partido é a referência básica. E é justamente essa variação que se tenta explicar para o conjunto de estados selecionados. Para chegar a uma medida da maior ou menor inclinação partidária dos deputados, o seu grau de partidarismo, foram utilizadas seis questões presentes nos questionários aplicados nas assembleias, descritas a seguir:

1. Quanto à lista de candidatos para deputados e vereadores, qual o (a) sr(a). acredita ser o tipo mais adequado para o Brasil?

2. Na última eleição, qual foi o fator mais importante para conseguir apoio políticoeleitoral de prefeitos e vereadores? E em segundo lugar?

3. Além dos recursos financeiros utilizados nas campanhas eleitorais, o apoio de pessoas, grupos ou organizações são fatores que também influenciam o resultado das urnas. Na opinião do (a) $\operatorname{sr}(a)$., qual dos seguintes apoios foi o mais importante para a sua vitória na última eleição? E em segundo lugar?

4. Quando há um conflito entre os interesses dos eleitores de sua região e as posições de seu partido, como o (a) sr(a). costuma votar?

5. O tema da disciplina partidária dos deputados suscita tradicionalmente opiniões muito diversas. Com qual das afirmações a seguir o (a) $\operatorname{sr}(a)$. concorda mais?

6. Com a possibilidade de perda de mandato por mudança de partido pelo deputado, qual das alternativas o (a) sr(a). acha que deveria ser aplicada?

Para a elaboração do índice de partidarismo, as questões foram tratadas como variáveis dummy em que o valor (0) significava uma posição de caráter mais individualista e o valor (1) uma posição de caráter partidário. No questionário aplicado na legislatura 2007-2011, a pergunta sobre o tipo de lista oferecia três opções ao entrevistado: (a) aberta; (b) fechada; (c) outro tipo de lista. Os que assinalaram a última alternativa foram convidados a explicitar sua opção. Quando isso apontou no sentido de uma lista preordenada e flexível ou de uma lista fechada no contexto de um sistema eleitoral de tipo alemão, a resposta foi classificada como indicando comportamento mais partidário (1). No questionário aplicado na legislatura seguinte (2011-2015) as alternativas para a lista foram: (a) aberta; (b) preordenada e fechada; (c) preordenada e flexível. Nesse caso as opções (b) e (c) receberam (1). A segunda e a terceira questões ofereciam várias alternativas de resposta. Deputados que assinalaram "suas relações partidárias" na segunda e "o apoio do partido" na terceira tiveram sua 
resposta classificada como $(1)^{2}$. Na quarta questão, o cartão de resposta oferecia as opções "sempre com o partido" e "sempre de acordo com os interesses dos eleitores de sua região". Alternativas verbalizadas pelos entrevistados, e não mostradas no cartão de respostas, foram tratadas como missing na análise.

A quinta questão, sobre disciplina partidária, sofreu alteração nas alternativas de resposta entre uma rodada da pesquisa e outra. No questionário aplicado na primeira legislatura, o cartão de resposta exibia a alternativa "alguns temas devem estar sujeitos à disciplina partidária e outros não". Ainda que se solicitasse ao entrevistado a explicitação dos temas, a categorização das respostas mostrou-se difícil: em um grande número de casos o resultado era ambíguo e misturava, por exemplo, questões de consciência com interesses eleitorais. Como será possível perceber a seguir, essa alternativa não foi levada em conta na criação do índice. No questionário aplicado na legislatura 2011-2015, a alternativa foi retirada do cartão, de forma a induzir o entrevistado a escolher entre "permitir que o deputado vote de acordo com sua opinião" e "exigir disciplina". Respostas que remetiam ao tema em questão foram tratadas como missing e, portanto, não incorporadas à análise.

Finalmente, a sexta questão também sofreu alterações entre um momento e outro. A formulação aqui apresentada foi utilizada na segunda rodada da pesquisa. Por ocasião da primeira rodada solicitava-se ao entrevistado escolher entre permitir a troca de legenda (mantendo o mandato) ou coibi-la (sujeitando o migrante à perda da cadeira). Na legislatura 2011-2015, em função da decisão tomada pelo TSE sobre o tema e da discussão subsequente, foram apresentadas aos entrevistados as seguintes opções: (a) Voltar à ampla liberdade, que permitia a mudança de partido sem risco de perda de mandato; (b) Permitir a abertura de uma "janela" que cria uma única oportunidade para a mudança um ano antes do pleito; (c) Manter a decisão do TSE que abre a possibilidade de perda do mandato para o legislador que muda de partido. Para a elaboração do índice, as respostas (a) e (b) foram consideradas equivalentes à opção pela manutenção do mandato (apresentada na primeira rodada) e categorizadas como (0).

O índice foi construído somando as respostas dadas ( 0 ou 1 ) de cada deputado ${ }^{3}$. No entanto, foi preciso lidar com o fato de que 129 entrevistados (13,6\% do total) declararam não ter recebido apoio de prefeitos ou vereadores em sua eleição (segunda

\footnotetext{
2 No caso da segunda questão, as demais opções eram: (a) suas relações pessoais ou familiares com prefeitos e/ou vereadores; (b) a intermediação de lideranças locais; (c) a ocupação prévia do cargo de prefeito em um município importante; (d) a realização de obras na região, em outras ocasiões; (e) o seu apoio à campanha deles, quando eles foram candidatos. No caso da terceira questão, as demais opções eram: (a) o apoio de prefeitos de sua região; (b) o apoio de vereadores de sua região; (c) o apoio de outras lideranças de sua região; (d) o apoio de líderes empresariais; (e) o apoio da sua igreja; (f) o apoio de movimentos sociais e sindicais; ( $g$ ) o apoio da sua família.

${ }^{3} \mathrm{Na}$ construção do índice, cada questão teve o mesmo peso, uma vez que não havia justificativa para valorizar mais umas do que outras.
} 
questão). Outros 146 entrevistados (15,6\%), na quarta questão, disseram preferir abster-se, não comparecer à votação ou, ainda, que sua posição dependeria do assunto em questão. Finalmente, na quinta questão, 313 (32,9\%) deputados entrevistados por ocasião do primeiro survey responderam que "alguns temas devem estar sujeitos à disciplina partidária e outros não". Em nenhum dos casos a resposta poderia ser considerada na elaboração do índice. Para evitar a perda de um grande número de casos, optou-se por fazer uma ponderação, generalizando o procedimento de modo a valer para todas as questões. Em outras palavras, na elaboração do índice foram considerados todos os casos em que os deputados responderam pelo menos cinco das seis questões acima relacionadas ${ }^{4}$. A soma obtida com as respostas foi dividida pelo total de questões respondidas. Dessa forma chegou-se à seguinte sequência de valores: 0,$0 ; 0,17 ; 0,2 ; 0,33 ; 0,4 ; 0,5 ; 0,6 ; 0,67 ; 0,8 ; 0,83$ e $1,0(0,17$ correspondendo a 1 ponto em seis questões; 0,2 correspondendo a 1 ponto em cinco, e assim sucessivamente). Para a utilização no modelo, os valores foram agrupados como segue: $0,0=0 ; 0,17$ e $0,2=1 ; 0,33$ e $0,4=2 ; 0,5 ; 0,6$ e $0,67=3 ; 0,8 ; 0,83$ e $1,0=4$.

Ao fim e ao cabo, foi possível chegar a um índice de partidarismo com variação de 0 (perfil menos partidário) a 4 (perfil mais partidário). A Tabela 1 mostra a distribuição do índice em termos percentuais nos estados analisados, bem como o valor médio alcançado em cada um deles ${ }^{5}$ :

\footnotetext{
${ }^{4}$ O que ocorreu em 899 dos 952 casos contidos no banco de dados. Foram perdidos 53 casos.

5 Para o cálculo do índice, as duas legislaturas foram tratadas como uma só integrando-se os bancos de dados, o que, de resto, fica evidente pelo número total de casos (899). Ao final, por ocasião da verificação das hipóteses, será possível perceber que a mudança de um período legislativo a outro não possui qualquer impacto sobre o grau de partidarismo encontrado.
} 
Tabela 1

Distribuição de frequência (\%) e valor médio do índice de partidarismo nos estados

\begin{tabular}{|c|c|c|c|c|c|c|c|}
\hline \multirow{2}{*}{ Estado } & \multicolumn{5}{|c|}{ Valor do índice de partidarismo } & \multirow{2}{*}{$\begin{array}{c}\text { Total } \\
\text { ( N) }\end{array}$} & $\begin{array}{c}\text { Í ndice de } \\
\text { partidarismo } \\
\text { ( M) }\end{array}$ \\
\cline { 2 - 5 } & $\mathbf{0}$ & $\mathbf{1}$ & $\mathbf{2}$ & $\mathbf{3}$ & $\mathbf{4}$ & & 2,6 \\
\hline SC & 6,1 & 13,6 & 22,7 & 31,8 & 25,8 & 66 & 2,6 \\
\hline RS & 4,8 & 15,7 & 24,7 & 26.5 & 28,9 & 83 & 2,2 \\
\hline SP & 16,1 & 17,9 & 16,1 & 28,6 & 21,4 & 112 & 2,1 \\
\hline PA & 18,5 & 10,8 & 27,7 & 30,8 & 12,3 & 65 & 1,9 \\
\hline PE & 18,1 & 22,2 & 22,2 & 22,2 & 15,3 & 72 & 1,8 \\
\hline BA & 23,0 & 20,0 & 21,0 & 22,0 & 14,0 & 100 & 1,6 \\
\hline GO & 20,3 & 35,6 & 15,3 & 25,4 & 3,4 & 59 & 1,6 \\
\hline CE & 26,9 & 22,4 & 23,9 & 17,9 & 9,0 & 67 & 1,5 \\
\hline MG & 24,8 & 27,4 & 23,9 & 15,9 & 8,0 & 113 & 1,4 \\
\hline RJ & 36,0 & 15,7 & 18,0 & 25,8 & 4,5 & 89 & 1,3 \\
\hline MT & 30,3 & 24,2 & 30,3 & 12,1 & 3,0 & 33 & 1,2 \\
\hline TO & 30,0 & 32,5 & 20,0 & 15,0 & 2,5 & 40 & 1,9 \\
\hline Total (N) & 186 & 187 & 194 & 211 & 121 & 899 & \\
\hline
\end{tabular}

Fonte: Elaboração própria com base em dados do Projeto "Trajetórias, perfis e padrões de interação de legisladores estaduais em 12 unidades da Federação".

A variação do índice e o contraste entre os extremos da tabela são expressivos. Nos estados do Rio Grande do Sul e Santa Catarina, 57,6\% e 55,4\% dos entrevistados estão classificados nas posições 3 e 4, respectivamente. Já nos estados de Mato Grosso e Tocantins as mesmas posições foram ocupadas por apenas 15,1\% e 17,5\% dos entrevistados. Em relação aos resultados obtidos por ocasião do estudo feito apenas com a legislatura 2007-2011 (Melo, 2011), as posições extremas se mantiveram inalteradas, o mesmo valendo para os estados que aparecem logo a seguir - São Paulo e Rio de Janeiro.

\section{Estabilidade da competição eleitoral e sistemas partidários estaduais}

Em artigo recente, Luna e Altman (2011) defendem a ideia de que o conceito de institucionalização dos sistemas partidários seja tratado de forma bidimensional. Segundo os autores, não haveria razão para supor que os indicadores originalmente propostos por Mainwaring e Scully (1995) devam necessariamente "andar juntos". Isso abre a possibilidade de que um sistema partidário possa ser considerado "institucionalizado" em uma dimensão, aquela que remete à estabilidade da competição eleitoral, mas não em outra - a referente ao enraizamento dos partidos. E é com base na capacidade de desenvolver um padrão estável de competição política que aqui se pretende distinguir os sistemas partidários nos estados analisados. 
A discussão pode ser iniciada lembrando que, graças à dinâmica estabelecida na competição pela presidência da República até 2014, o sistema partidário brasileiro tem evoluído de forma positiva. Nas duas últimas décadas, a interação entre os principais partidos brasileiros adquiriu um determinado padrão, tornando possível delinear, com clareza, a estratégia dos principais competidores. Por um lado, nem todos os partidos jogam em todas as arenas possíveis. Nem todos competem pela presidência da República e são poucos os competidores efetivos pelos governos estaduais - a maioria dos partidos simplesmente joga suas fichas na eleição de boas bancadas para o Congresso Nacional e Assembleias Legislativas. Por outro, entre 1994 e 2014, o sistema partidário nacional manteve-se estruturado em torno de dois polos, um capitaneado pelo PT e outro pelo PSDB. Entre os dois "pontos de amarração", passou a flutuar um terceiro conjunto de partidos que, valendo-se das bancadas eleitas para o Congresso, mantêm em comum a disposição e a possibilidade de aderir ao governo de plantão (Melo e Câmara, 2012; Melo, 2015).

No plano regional, contudo, a situação é diferente. Países nos quais as unidades subnacionais são dotadas de elevado nível de autonomia tendem a apresentar dinâmicas políticas regionalmente diferenciadas. No caso do atual período democrático brasileiro, tal tendência foi acentuada pelo fato de que - ao contrário do ocorrido durante a República de 1946 - desde o final dos anos 1980 o sistema partidário deixou de contar com partidos dotados de uma capilaridade que os possibilitasse apresentar-se como competidores efetivos em todo o território nacional. Com isso a diferenciação entre as dinâmicas políticas estaduais se acentuou, a depender da força das maiores legendas nacionais em cada contexto e da interação estabelecida entre elas.

Ao fim e ao cabo, o quadro encontrado nos estados é muito diferenciado, sendo possível encontrar: a) sistemas partidários que assumiram um padrão semelhante ao nacional, como seria o caso de São Paulo ou Minas Gerais; b) estados nos quais a competição não se estruturou em torno de PT e PSDB, como em Santa Catarina ou no Rio Grande do Sul; ou, ainda, c) situações em que sequer é possível delinear um padrão de interação entre os competidores e o que se observa é um quadro de partidos em constante estado de fluxo, mas não um sistema partidário: é o que ocorre, por exemplo, no Rio de J aneiro.

Para os objetivos deste artigo interessa distinguir os 12 estados analisados no que se refere ao grau de estabilidade da competição eleitoral, uma vez que se supõe haver uma relação entre essa variável e o perfil mais ou menos partidário revelado pelos deputados nas entrevistas realizadas. Nos estados onde os partidos estruturam de forma mais clara a competição, gerando ganhos de estabilidade, sua importância será mais destacada, se não para a escolha do eleitor (isso é algo que aqui não poderá ser verificado), certamente para a constituição das carreiras políticas, o que, presume-se, tenderá a impactar a maneira como um deputado valora a sigla à qual pertence. 
Para classificar os sistemas partidários em função do grau de estabilidade na competição eleitoral foram definidos cinco indicadores. Tradicionalmente utilizado na discussão sobre institucionalização, o índice de volatilidade responde pelos três primeiros, com base nas eleições para as Assembleias Legislativas, a Câmara dos Deputados e os governos estaduais entre 1982 e 2010. Como é comum na literatura (Mainwaring e Torcal, 2005) em todos os casos foi utilizada a média para o período ${ }^{6}$. Como já ressaltado pela literatura (Melo, 2004; Rennó, Peres e Ricci, 2011; Bohn e Paiva, 2009), observa-se grande variação entre as unidades da Federação. O valor encontrado para a volatilidade nas eleições legislativas nos estados de Santa Catarina e Rio Grande do Sul é cerca de metade daquele verificado para os cinco primeiros estados na Tabela 2 - Mato Grosso, Rio de Janeiro, Pernambuco, Tocantins e Ceará. Por razões óbvias, os valores da volatilidade para o governo estadual são maiores para todos os casos, mas mesmo assim os dois estados do Sul, agora acompanhados por São Paulo, situam-se pelo menos a dez pontos de distância de outros cinco estados (Mato Grosso, Rio de J aneiro, Pernambuco, Tocantins e Pará).

O quarto indicador é o percentual de deputados eleitos para a Câmara que mudaram de partido entre 1982 e 2014 nos estados, considerando-se apenas os titulares. A suposição feita é a de que uma alta taxa de deputados migrantes aumenta a instabilidade dos resultados eleitorais, uma vez que o deputado que troca de partido leva parcela de seu eleitorado. Não é por outra razão que a incidência das migrações se encontra associada ao índice de volatilidade nos estados (Melo, 2004). Novamente Rio Grande do Sul e Santa Catarina ${ }^{7}$ apresentam os menores índices em contraposição a Mato Grosso, Rio de Janeiro, Pernambuco e Tocantins.

A diferença em termos percentuais entre a votação, no primeiro turno, do governador eleito e de seu partido para a Assembleia Legislativa fornece o quinto indicador. O suposto aqui é que naqueles estados onde tais votações encontram-se mais próximas os partidos são referenciais mais fortes no momento da escolha eleitoral. Os valores apresentados referem-se à média para o período considerado. Novamente a diferença entre os extremos da tabela é significativa: a distância média entre as

\footnotetext{
${ }^{6}$ Este artigo foi elaborado e submetido ainda em 2014 e, portanto, sem que fosse possível incorporar os resultados desse último ano no cálculo da volatilidade. Seja como for, em um período longo como esse, diversos partidos surgiram, desapareceram, fundiram-se ou trocaram de nome. Nos casos em que os partidos disputaram a eleição pela primeira vez, a totalidade da votação obtida foi computada para efeito do cálculo da volatilidade. O mesmo raciocínio aplicou-se a partidos que de uma eleição a outra deixaram de concorrer. Partidos que trocaram de nome foram tratados como uma mesma legenda. Por fim, quando dois ou mais partidos se fundiram, a votação obtida separadamente foi comparada àquela conseguida após a fusão.

7 Particularmente no último período considerado, a legislatura 2011-2015, o sistema partidário catarinense sofreu o impacto da criação do PSD e da desidratação do DEM. Ainda que em menor grau, a mesma observação vale para São Paulo.
} 
votações para o governador e seu partido é de 17,2\% em São Paulo, o estado com melhor desempenho no quesito, e de $36,9 \%$ no Mato Grosso ou em Pernambuco:

Tabela 2

Í ndice de estabilidade da competição eleitoral estadual

\begin{tabular}{|c|c|c|c|c|c|c|}
\hline \multirow{2}{*}{ Estado } & \multicolumn{3}{|c|}{ Volatilidade } & \multirow{2}{*}{$\begin{array}{c}\text { Migrantes } \\
\text { (\%) }\end{array}$} & \multirow{2}{*}{$\begin{array}{l}\text { Diferença de } \\
\text { voto } \\
\text { gov./ partido }\end{array}$} & \multirow{2}{*}{$\begin{array}{c}\text { Índice de } \\
\text { estabilidade }\end{array}$} \\
\hline & Assembleia & Câmara & $\begin{array}{l}\text { Governo } \\
\text { estadual }\end{array}$ & & & \\
\hline MT & 36,1 & 33,0 & 67,2 & 42,2 & 36,9 & 2,85 \\
\hline RJ & 34,0 & 33,1 & 58,1 & 32,3 & 30,8 & 3,12 \\
\hline $\mathrm{PE}$ & 33,0 & 31,2 & 52,3 & 30,3 & 36,9 & 3,16 \\
\hline TO & 29,0 & 41,0 & 37,0 & 41,7 & 29,4 & 3,22 \\
\hline CE & 36,0 & 33,0 & 47,4 & 26,7 & 26,3 & 3,31 \\
\hline MG & 30,8 & 28,4 & 43,9 & 25,2 & 33,6 & 3,38 \\
\hline BA & 30,3 & 28,8 & 39,5 & 31,8 & 28,1 & 3,41 \\
\hline GO & 30,9 & 30,8 & 42,6 & 20,0 & 24,1 & 3,52 \\
\hline PA & 31,0 & 27,0 & 48,2 & 17,0 & 24,1 & 3,53 \\
\hline SP & 20,6 & 23,7 & 33,1 & 22,5 & 17,2 & 3,83 \\
\hline SC & 17,6 & 16,0 & 36,6 & 15,6 & 21,2 & 3,93 \\
\hline RS & 17,7 & 17,9 & 34,2 & 6,8 & 21,5 & 4,02 \\
\hline
\end{tabular}

Fonte: Elaboração própria com base nos sites do TSE e Câmara dos Deputados e em Melo (2004).

Como se pode perceber pela Tabela 2, os indicadores são fortemente correlacionados. Para qualquer par de indicadores a relação, medida pelo coeficiente de Pearson, é de no mínimo 0,606, significativo a 0,01. O passo seguinte foi estabelecer um índice que permitisse a comparação entre os estados no modelo a ser utilizado. Para tanto o procedimento foi simples: os valores obtidos em cada célula foram normalizados e somados, gerando valores de 0 a 5 . Dessa forma, quanto mais alto o resultado, mais instável seria a competição eleitoral no estado. No entanto, para tornar o resultado mais intuitivo, optou-se por fazer com que a valores mais altos correspondessem situações de maior estabilidade. Para tanto, os valores anteriormente obtidos foram subtraídos de $5^{8}$. Em um extremo da tabela encontram-se os estados onde a competição eleitoral apresenta maior estabilidade: Rio Grande do Sul, Santa Catarina e São Paulo. Por outro lado, Mato Grosso, Rio de Janeiro e Pernambuco possuem os cenários mais voláteis.

\footnotetext{
${ }^{8}$ Os valores obtidos com a soma dos indicadores normalizados haviam sido (de cima a baixo na tabela): 2,$15 ; 1,88 ; 1,84 ; 1,78 ; 1,69 ; 1,62 ; 1,59 ; 1,48 ; 1,47 ; 1,17 ; 1,07$ e 0,98 . Os valores mostrados na última coluna da Tabela 2 correspondem ao resultado da subtração de cada um deles de 5 .
} 


\section{Mudando o nível de análise: o que caracteriza os deputados partidários?}

Nesta seção serão apresentadas as hipóteses formuladas com o objetivo de discutir a relação entre determinadas características individuais dos legisladores entrevistados e seu grau de partidarismo. A primeira hipótese refere-se ao tempo de filiação. De acordo com Marenco dos Santos (2001), lealdades partidárias necessitam tempo para sedimentar. Na mesma linha, em trabalho sobre as migrações partidárias no Brasil, Melo (2004) mostrou que deputados com mais de oito anos de filiação a uma legenda possuíam quatro vezes menos chance de mudar de partido do que aqueles filiados a menos de quatro anos. O maior tempo de permanência do deputado em uma legenda indica a presença de incentivos, coletivos ou seletivos, preciosos para a carreira e conduz à valorização do label partidário. A hipótese, portanto, é de que deputados com maior tempo de filiação apresentem perfil mais partidário. Os dados sobre filiação foram obtidos diretamente com os deputados. Dos 952 deputados entrevistados, 7\% haviam se filiado a seu partido na legislatura em curso por ocasião da pesquisa. Outros $23,5 \%$ estavam em seu partido desde a legislatura anterior. 17,9\% e 10,7\% haviam se filiado respectivamente há duas e três legislaturas. Finalmente, $38,8 \%$ dos entrevistados estavam em seu partido há quatro ou mais legislaturas ${ }^{9}$.

A segunda hipótese sustenta que deputados situados à esquerda apresentariam perfil mais partidário. Novamente, estudos sobre a migração partidária apontam nessa direção. Segundo Nicolau (1996) e Melo (2004), deputados vinculados a partidos de esquerda abandonam seus partidos com menos frequência que os demais, indicando maior apreço à sigla pela qual se elegeram. Por sua vez, Mainwaring (1999) destaca que apenas entre os deputados de esquerda no Brasil é majoritária a percepção de que os esforços partidários são mais importantes do que os individuais para o sucesso eleitoral. O achado é corroborado, como mostram Ames, Pereira e Rennó (2011), pelos dados coletados pela Pesquisa Legislativa Brasileira, coordenada por Power e Zucco (2011).

Para além das evidências empíricas, duas linhas de argumentação podem ser desenvolvidas na fundamentação da hipótese. Por um lado, é possível postular que partidos de esquerda são mais propensos a assumir características programáticas (Przeworski e Sprague, 1986), o que os leva a incrementar o grau de responsabilização política da liderança, a participação e a democracia internas (Strom, 1990). O resultado é o incentivo ao fortalecimento dos vínculos entre a organização e seus membros. Nos termos de Panebianco (1982), em partidos desse tipo os incentivos coletivos manteriam sua importância, ao contrário do que tenderia a ocorrer naqueles "puramente"

\footnotetext{
${ }^{9}$ Vinte deputados não souberam ou não quiseram responder à questão.
} 
eleitorais, em que os incentivos seletivos seriam largamente dominantes, se não únicos ${ }^{10}$.

Por outro lado, o pertencimento aos partidos de esquerda também pode possibilitar um cálculo de ordem mais pragmática aos deputados e que remete à possibilidade de que os membros desses partidos se beneficiem do controle de recursos de campanha e de estratégias eleitorais coletivas desenvolvidas por suas organizações, como mostrou Samuels (1997) para o caso do PT. No Partido dos Trabalhadores, a ênfase conferida à legenda sempre reduziu os custos de campanha e possibilitou, em especial até 2002 , a eleição de deputados com votação mais baixa do que a necessária nos demais partidos de porte médio e grande. O mesmo vale para o PC do B, que, ao centrar seus recursos em um número reduzido de candidatos, geralmente em coligação com o PT, potencializa as chances dos indicados. Os membros dos partidos de esquerda também podem contar com outro importante recurso eleitoral: os laços com os militantes oriundos dos movimentos sociais. Mesmo depois de moderar suas posições e abandonar muitas de suas bandeiras iniciais, o PT, de acordo com Amaral (2011), continua a manter vínculos com a sociedade civil. No mesmo sentido, Samuels e Zucco (2014, p. 4) argumentam que apenas o PT, dentre os maiores partidos brasileiros, fez da expansão de sua malha organizacional "part of a top-down strategy to engage organized civil society at the grass roots", ao passo que no PMDB e no PSDB a organização municipal serve apenas como instrumento para que os políticos locais formalizem suas candidaturas. Pode-se dizer, portanto, que para os políticos de esquerda a relação entre sucesso eleitoral e estrutura partidária tende a ser mais forte do que no caso dos que se perfilam ao centro e à direita.

Para a operacionalização da hipótese foi utilizada a questão que solicitava aos entrevistados a autolocalização em uma escala de 1 a 10, em que 1 representava a posição mais à esquerda. Como é comum em contextos de "direita envergonhada" (Power e Zucco, 2011), 70\% dos entrevistados situaram-se entre as posições 1 e 5, com o percentual de respondentes tornando-se mais escasso na medida em que se caminha para a direita ${ }^{11}$.

A terceira hipótese aventada é de que deputados com tendência a exercer o mandato sob uma ótica mais universalista, em contraposição àqueles de orientação mais particularista, apresentariam perfil mais partidário. Na literatura especializada é comum a ênfase nos aspectos negativos das políticas de caráter distributivo, aquelas marcadas por ganhos concentrados e custos difusos, associando-as ao clientelismo, à

\footnotetext{
10 Cabe ressaltar que a unidade de análise neste artigo é o deputado e não o partido. Mas a quase totalidade $(92 \%)$ dos entrevistados que se localizaram nas posições mais à esquerda do contínuo era filiada a partidos também situados à esquerda (PT, PSOL, PC do B, PSB, PDT e PPS).

11 18,1\% situaram-se nas posições 1 e 2. 52,1\% ficaram entre 3 e 5 . As posições entre 6 e 10 foram ocupadas por $29,8 \%$ dos entrevistados.
} 
patronagem ou à ineficiência (Shepsle e Weingast, 1981) ${ }^{12}$. Para os objetivos deste artigo, interessa ressaltar a suposição, também comum, de que o particularismo tende a prevalecer em contextos em que predomina o voto personalizado (Kitschelt, 2000), processo que poderia ser mitigado com a presença mais destacada dos partidos (Shugart, 2001). Ou seja, deputados que constroem seu mandato prioritariamente com base no atendimento de demandas específicas tendem a se apoiar mais em relações de caráter individual, dispensando, ou minimizando, a importância da mediação partidária. De acordo com Linz (2002), aqueles que representam "interesses especiais" entram com mais frequência em conflito com seus líderes, os quais estariam mais preocupados com a preservação do label do partido e voltados para a aprovação de iniciativas de impacto mais amplo.

$\mathrm{Na}$ literatura nacional, trabalhos recentes formulam suas suposições no mesmo sentido. Em estudo sobre os legisladores estaduais brasileiros, Castro, Nunes e Anastasia (2009, p. 982) encontraram resultados que thes permitiram afirmar que, "quanto mais à direita se localiza o partido, maior a probabilidade de que o deputado se comporte de forma particularista". Testando a hipótese de que deputados partidários seriam "menos inclinados ao engajamento parlamentar orientado para pork e intermediação de demandas", Inácio (2011, p. 172) encontra resultados distintos, refutando tal hipótese no caso dos legisladores nacionais, mas corroborando-a quando o foco da pesquisa se volta para as Assembleias Legislativas ${ }^{13}$. Resultados inconclusivos são também apresentados por Lemos e Ricci (2011, p. 224 e 227). Utilizando os dados da Pesquisa Legislativa Brasileira para o período compreendido entre 1997 e 2009, os autores mostram que, em média, $62 \%$ dos deputados considerados "paroquialistas" preferem votar de acordo com sua própria opinião do que seguir o partido, mas, por outro lado, o percentual dos que disseram ser a favor da "fidelidade partidária" chega a $51,9 \%$, em média, para o mesmo período ${ }^{14}$.

\footnotetext{
12 Para uma visão distinta, ver Ames, Pereira e Rennó (2011, p. 241), para quem "as políticas de tipo pork barrel podem ser um mecanismo eficiente de representação política e accountability no Brasil". Ainda segundo os autores (p. 246), "se é pork o que os eleitores querem e pork é o que os parlamentares entregam, especialmente quando essas políticas são necessárias, então as políticas locais podem não implicar nenhuma ruptura no processo representativo". Sem dúvida, o argumento é forte, desde que não se perca de vista que um dos méritos da representação, se não o maior, é justamente possibilitar que os parlamentares se distanciem do que os eleitores querem de forma imediata.

13 Ainda segundo a autora, no caso dos deputados estaduais, "o partidarismo revelou um efeito consistente, ou seja, a menor propensão a adotar políticas distributivas tanto entre os deputados em geral quanto no interior da coalizão de governo" (Inácio, 2011, p. 201).

14 Tanto Inácio como Lemos e Ricci dialogam com Hagopian, Gervasoni e Moraes (2009), para os quais seria possível constatar uma modificação na percepção dos legisladores nacionais quanto aos ganhos advindos da reputação partidária, em função do processo de polarização e diferenciação programática ocorrido durante a década de 1990. No entanto, os autores destacam aspectos distintos. Para Inácio (2011, p. 198), a "manifestação de lealdade ao partido não colide com a disposição do legislador em investir, ainda que seletivamente, em atividades de cunho particularista". Lemos e Ricci (2011, p. 229), por sua vez, preferem ressaltar que o "grau considerado alto de apoio ao princípio da fidelidade partidária" é consistente com os achados de Hagopian, Gervasoni e Moraes.
} 
Para a medida do grau de particularismo dos deputados foi criado um índice com base nas seguintes questões:

1. Na sua atuação como parlamentar, qual é a função, dentre as enumeradas a seguir, a que o (a) sr(a). dá mais importância? E em segundo lugar?

2. $\mathrm{O}(\mathrm{a}) \mathrm{sr}(\mathrm{a})$. acredita representar prioritariamente os interesses [...];

3. Com que frequência o (a) $\operatorname{sr}(a)$. tem realizado as seguintes atividades [...];

4. Gostaria de saber com que frequência o (a) $\operatorname{sr}(a)$. utiliza os meios listados neste cartão para informar os seus eleitores sobre sua atuação parlamentar [...];

5. Das atividades realizadas pelos parlamentares, listadas a seguir, qual o (a) $\operatorname{sr}(a)$. considera a mais importante para um candidato a deputado estadual se reeleger? $\mathrm{E}$ em segundo lugar?

Para cada questão o entrevistado poderia pontuar (0) ou (1). Pontuaria (1) quando: a) assinalasse, em primeiro ou segundo lugar, a alternativa "propor emendas ao orçamento estadual que beneficiem a sua região" para a primeira pergunta; b) dissesse representar prioritariamente interesses "dos eleitores de sua região" ou de "determinado segmento (social, religioso, econômico) dos cidadãos de seu estado"; c) na terceira questão afirmasse realizar, com muita frequência, as atividades de "atender ou encaminhar os pleitos de seus eleitores" ou de "tratar junto à burocracia das demandas de prefeitos de sua região"; d) utilizasse com muita frequência "um escritório de representação em sua cidade" para informar os eleitores sobre sua ação parlamentar; f) na última questão, assinalasse, em primeiro ou segundo lugar, a opção "conseguir recursos para sua base eleitoral". O índice variou de 0 a 6 , com 60,1\% dos entrevistados concentrando-se nas posições 4, 5 e 6, as mais particularistas.

A quarta hipótese formulada foi a de que deputados mais progressistas, em contraposição àqueles mais conservadores, tenderiam a apresentar perfil mais partidário. Quando se trata o espaço da competição política de forma multidimensional, a clivagem liberal (progressista) / conservador aparece como uma das dimensões a serem consideradas (Sartori, 2005; Tarouco e Madeira, 2013; Bernabel, 2013). Como diz Sartori (2005, p. 395),

las etiquetas liberal-conservador suelen asimilar-se, por lo menos con fines comparativos, a izquierda-derecha. Pero los dos conjuntos de etiquetas difieren fundamentalmente en que al primero no se le puede privar totalmente de contenido cognoscitivo-informativo, mientras que el segundo consiste de cajas vacías que, en principio, se pueden llenar y rellenar a voluntad.

De fato, não seria possível classificar as políticas levadas a cabo pelos países do antigo bloco soviético como liberais, embora estas pudessem ser classificadas como de 
esquerda. A ênfase nas políticas redistributivas e no papel do Estado não necessariamente anda junto com posturas mais abertas no que se refere ao comportamento humano em sociedade. Por isso, embora seja possível associar a defesa das minorias e dos direitos humanos - uma posição claramente progressista/liberal com a trajetória da esquerda, essa associação pode ser problematizada com base, por exemplo, no tratamento dado aos homossexuais nos países socialistas. Por outro lado, e indo além de Sartori, o próprio conteúdo do conservadorismo nem sempre é fácil de ser caracterizado. Como mostram Vincent (1995) e Ware (1996), a emergência da Nova Direita a partir de meados dos anos 1970 fez com que o conservadorismo se mostrasse fortemente tencionado pela dimensão econômica, assumindo posições liberais ortodoxas e abandonando todas as justificativas anteriores que pudessem remeter a um papel mais ativo do Estado. A esse deslocamento para a direita correspondeu outro, dessa vez para o centro, no que se refere às políticas sociais, tendo em vista a necessidade de manter o eleitorado de classe média ${ }^{15}$.

Nas análises sobre o Legislativo brasileiro essa dimensão não tem merecido destaque. Zucco e Lauderdale (2011) e Zucco (2011), ao abordarem a Câmara dos Deputados, por exemplo, comparam o impacto da clivagem esquerda/direita à clivagem estratégica - governo versus oposição - para concluir pela predominância da segunda nas disputas políticas congressuais. Bernabel (2013), por sua vez, argumenta que a dimensão "econômica" (esquerda/direita) possui maior poder explicativo (do que a "social-liberal/conservative") e pode ser utilizada para estimar como o legislador votará em outras dimensões. Na mesma direção, Melo e Santos (2013), tendo como base survey realizado entre deputados estaduais na legislatura 2007-2011, mostram a existência de correlação entre o posicionamento ideológico dos deputados e suas respostas a questões comportamentais como a união civil de pessoas do mesmo sexo e a redução da maioridade penal ${ }^{16}$.

O ponto de partida aqui adotado é de que se existem motivos para esperar uma superposição entre as duas dimensões, por outro lado, convém não ignorar as diferenças assinaladas e, nesse sentido, explorar o que a dimensão progressista/conservador poderia informar acerca da relação entre deputados e partidos. A literatura não explora a questão por esse ângulo. Nesse sentido, é possível fazer referência às proposições de Weber (1982) e Lipset e Rokkan (1967), para os quais o surgimento e o desenvolvimento dos partidos políticos se encontram vinculados a determinadas condições socioestruturais e contextos institucionais. Ainda que tais referências remetam às democracias mais longevas, é possível argumentar que, no

15 Segundo Vincent (1995, p. 76), elementos libertários radicais da Nova Direita têm exigido a desregulamentação das drogas e da pornografia sob o argumento de que deixariam de ser problemas se estivessem disponíveis no livre mercado.

${ }^{16}$ Os autores utilizam os mesmos dados mobilizados para este artigo. 
Brasil, a relevância dos partidos e o grau de competitividade do sistema político ainda encontram-se vinculados ao tamanho dos municípios, embora o mesmo não possa ser dito a respeito da tese segundo a qual "partidos conservadores predominariam em municípios rurais, enquanto partidos de centro e esquerda prevaleceriam nos centros mais urbanos" (Marenco dos Santos, 2013, p. 18). Em outras palavras, seria razoável esperar que naqueles contextos mais tradicionais, ou conservadores no sentido "clássico" do termo, prevalecessem as relações de tipo personalista, ou familiares, na política, em vez da mediação dos partidos.

Nas duas rodadas da pesquisa, os deputados foram convidados a se posicionar contra ou a favor de alguns temas do debate contemporâneo. Foram considerados progressistas os que se manifestaram contra a redução da maioridade penal e a pena de morte, e a favor da descriminalização do uso de drogas, da união civil de pessoas do mesmo sexo, do aborto como direito das mulheres e da proibição da venda de armas de fogo. Exceção feita à questão sobre o aborto no questionário aplicado na legislatura 2007-2011, os entrevistados eram solicitados a se posicionar contra ou a favor sobre cada tema. A alternativa "depende" não constava no cartão de resposta, sendo assinalada apenas quando espontaneamente vocalizada. No caso do aborto, o questionário aplicado em 2007 utilizava uma escala de 1 a 10. Nesse caso, optou-se por considerar apenas as posições 1 e 2 como favoráveis à prática. As posições 3, 4 e 5 foram consideradas "depende" e as demais, "contra". Com base nessas questões foi possível chegar a um índice com variação de 0 a 6 , com o entrevistado pontuando (1) a cada vez que se pronunciava de forma progressista. Apenas 4,7\% dos deputados foram classificados na posição mais conservadora (0). Na posição (1) ficaram $15,8 \%$, na (2) $24,9 \%$, na (3) $23,7 \%$, na (4) e na (5) $16,1 \%$ e $9,3 \%$ respectivamente, enquanto $8,0 \%$ dos entrevistados ocuparam a posição mais progressista ${ }^{17}$.

A quinta hipótese defende que legisladores vinculados às igrejas evangélicas apresentarão perfil menos partidário. Segundo alguns autores (Pierucci, 1987, 1989; Mendonça e Velasques, 1990; Prandi, 1992; Freston, 1993) é possível afirmar que os evangélicos possuem um perfil mais conservador. Tal perfil estaria associado, segundo Prandi (1992), a uma pregação - dirigida aos eleitores - segundo a qual é preciso se manter longe do terreno da política e de tudo o que ela representa e à percepção de que o que vale é a defesa dos interesses e valores defendidos pela Igreja (o que muitas vezes assume a forma de uma "candidatura oficial"). Nesse contexto, faz pouco sentido esperar que tais deputados se sintam vinculados aos partidos pelos quais foram eleitos. Tal suposição é perfeitamente coerente quando se observa a trajetória dos deputados

\footnotetext{
17 Não foram registradas diferenças significativas quando são comparados os resultados para as duas legislaturas. No agregado, $58,7 \%$ dos entrevistados se posicionaram a favor da redução da maioridade penal; $60,5 \%$ a favor da proibição da venda de armas de fogo; $56,2 \%$ a favor da união civil de pessoas do mesmo sexo; $31,5 \%$ a favor da prática legal do aborto; $22,7 \%$ a favor da descriminalização do uso de drogas e $18,3 \%$ a favor da aplicação da pena de morte no país.
} 
evangélicos na Câmara dos Deputados: esses deputados distribuem-se pelas mais diversas legendas ao centro e à direita e trocam de partido com muita frequência. Para a operacionalização da hipótese, a variável foi transformada em uma dummy: os evangélicos receberam o valor (0) e os demais entrevistados (inclusive os que se declararam sem religião) ficaram com (1) ${ }^{18}$.

Finalmente, foi possível formular outras duas hipóteses, segundo as quais deputados com perfil menos partidário tenderiam a: (1) pertencer a famílias com tradição política; e (2) apresentar maior nível de renda. A primeira hipótese fundamenta-se na ideia de que no Brasil a existência de uma tradição política que passa de pai para filho ajusta-se melhor à categoria dos políticos "sem partido". Para operacionalizá-la foi utilizada a questão sobre a presença de familiares na política e agrupadas as respostas que apontavam a presença de pai/mãe/irmão(ã) de forma isolada ou associada a tio/avô.

A última hipótese, por sua vez, se baseia no argumento de que os vínculos entre os partidos e seus membros tendem a ser mais fortes quanto menor a autonomia econômica dos segundos. Como se sabe (Hobsbawm, 1977), a reivindicação de salário parlamentar constava da Carta do Povo, lançada pelo Cartismo em 1838. Nos termos de Weber (1982), os trabalhadores não eram nem "economicamente independentes" da remuneração que a atividade política pudesse lhes render, nem "economicamente disponíveis" para dedicar-se integralmente a essa atividade sem precisar preocupar-se com assuntos de ordem material. Panebianco (1982), por sua vez, ao discutir a relação entre líderes e membros como uma troca desigual, explica que os partidos de extração burguesa costumam enfrentar escassez de militância uma vez que os indivíduos a eles vinculados dispõem de canais alternativos de mobilidade - o que ocorre com menor frequência no caso dos partidos que têm entre os trabalhadores o seu principal "território de caça".

Evidentemente, é preciso considerar que aqui o foco se encontra nos deputados e não nos membros dos partidos e que os primeiros constituem uma elite relativamente ao conjunto da população. Mas isso não elimina o fato de que existam diferenças socioeconômicas significativas entre os legisladores, como as constatadas por Rodrigues (2002) em seu estudo sobre a Câmara dos Deputados ou, mais importante ainda, que tais diferenças se mantenham no que se refere ao financiamento de campanha e que para muitos deputados/candidatos, em especial para aqueles com baixa capacidade de autofinanciamento $^{19}$ e/ou de atração de doações provenientes de pessoas jurídicas, o

\footnotetext{
18 12,8\% dos entrevistados se declararam evangélicos; 9,8\% afirmaram não ter religião; e 4,8\% declararam outras religiões. Os demais se declararam católicos.

19 Para uma análise recente da capacidade de autofinanciamento dos candidatos à Câmara, ver Speck (2014).
} 
aporte de recursos do partido possa constituir fator decisivo no que se refere ao sucesso eleitoral.

Como havia dificuldades para realizar uma comparação direta entre as rendas, foi utilizada como proxy a questão por meio da qual se solicitava aos entrevistados que comparassem a renda recebida no exercício do mandato e a anterior: $22 \%$ declararam que a renda como legislador era inferior ou muito inferior; $29,1 \%$ disseram ser equivalente e $48,1 \%$ afirmaram ser superior ou muito superior.

\section{Testando as hipóteses}

Para o teste das hipóteses foi utilizado um modelo de regressão logística multinomial, uma vez que a variável dependente, no caso o índice de partidarismo, não se restringe a duas categorias e tampouco é possível sustentar que exista um ordenamento natural entre suas categorias. O modelo multinomial permite perceber como tais categorias se comportam sob a influência dos fatores escolhidos como preditores.

O modelo, mostrado a seguir, contou com nove variáveis independentes: estabilidade eleitoral, tempo de filiação, ideologia, particularismo, progressismo, religião, tradição familiar, renda e legislatura. As cinco primeiras não sofreram qualquer tipo de categorização e entraram no modelo como variáveis contínuas. Desse grupo, duas variáveis - ideologia e particularismo - tiveram seu ordenamento invertido, uma vez que a expectativa era de que deputados situados à esquerda e menos particularistas apresentassem perfil mais partidário -, dessa forma, para todas as variáveis o resultado esperado seria positivo, o que torna mais intuitiva a leitura do modelo ${ }^{20}$. As variáveis religião e tradição familiar foram tratadas como dummy. No primeiro caso, os evangélicos receberam o valor (0) enquanto os demais entrevistados ficaram com (1). No segundo, os que declararam pertencer a famílias com tradição na política receberam (0). No que se refere à renda, os que declararam receber, como deputados, renda inferior ou muito inferior à que faziam jus anteriormente foram classificados como (0); os que disseram ser equivalente receberam (1) e aqueles para os quais os valores recebidos eram superiores ou muito superiores ficaram com (2). A última variável, por óbvio, teve como objetivo avaliar o impacto da mudança de legislatura nos resultados.

Dessa forma, espera-se que os resultados sejam positivos para todas as variáveis, exceto no que se refere à legislatura. Espera-se que deputados de perfil mais partidário tenham mais chance de ser encontrados nos sistemas de maior estabilidade

\footnotetext{
20 Isso significa que, ao contrário do usual, os deputados situados à direita passaram a ser classificados como (1) e os situados à esquerda como (10). O mesmo vale para a outra variável - ao contrário do que foi apresentado na seção anterior, aqui os deputados particularistas receberam os menores scores (dito de outro modo, os "universalistas" ficaram nas posições mais altas).
} 
eleitoral, estejam filiados há mais tempo em seus partidos, se coloquem à esquerda, sejam mais universalistas (menos particularistas) no exercício do mandato, manifestem opiniões mais progressistas, não sejam vinculados a igrejas evangélicas, no exercício do mandato tenham renda superior à recebida anteriormente e não tenham parentes próximos com carreira política.

A Tabela 3 mostra os resultados. As variáveis estabilidade eleitoral e tempo de filiação são as que apresentam o melhor desempenho, mantendo valores significativos e no sentido esperado para as categorias (4), (3), (2) e (1), quando comparadas à categoria de referência (0). Deputados de perfil mais partidário, categoria (4), têm cerca de $910 \%$ a mais de chance de estar nos estados onde a competição eleitoral é mais estável do que os deputados da categoria de referência, os de perfil menos partidário (0). De maneira consistente, os percentuais caem para $258 \%$, quando se consideram os pertencentes à categoria (3) e chegam a seus níveis mais baixos - $161 \%$ e $171 \%$ - para o caso das categorias (2) e (1), sempre relativamente à categoria (0). Da mesma forma, os entrevistados de perfil mais partidário possuem $245 \%$ a mais de chance de serem encontrados entre aqueles que possuem maior tempo de filiação do que entre os novatos nas siglas. Novamente, os percentuais de chance diminuem de forma consistente na medida em que se caminha na direção dos perfis menos partidários ( $113 \% ; 62 \%$ e $21 \%$ a mais de chance) e a relação entre as variáveis mantém-se significativa mesmo quando os deputados da categoria (1) são comparados aos da categoria de referência (0): 
Tabela 3

Coeficiente de regressão multinomial para partidarismo ${ }^{21}$

\begin{tabular}{|c|c|c|c|c|c|c|}
\hline & \multirow{2}{*}{ Índice de partidarismo } & \multirow{2}{*}{ B } & \multirow{2}{*}{ Sig. } & \multirow{2}{*}{$\operatorname{Exp}(B)$} & \multicolumn{2}{|c|}{ Intervalo de confiança } \\
\hline & & & & & Inferior & Superior \\
\hline \multirow{10}{*}{1} & Intercept & $-5,790$ &, 000 & & & \\
\hline & Estabilidade eleitoral & ,997 &, 012 & 2,711 & 1,246 & 5,896 \\
\hline & Tempo de filiação & , 196 & 031 & 1,217 & 1,018 & 1,454 \\
\hline & Ideologia deputado & 057 &, 301 & 1,059 &, 950 & 1,179 \\
\hline & Particularismo & 095 &, 250 & 1,099 & ,936 & 1,292 \\
\hline & Progressismo &, 022 & 805 & 978 &, 820 & 1,167 \\
\hline & Religião & ,731 & ,015 & 2,077 & 1,152 & 3,745 \\
\hline & Renda & 028 & ,841 & 1,028 & ,785 & 1,347 \\
\hline & Tradição familiar &,- 127 &, 569 & 881 &, 569 & 1,363 \\
\hline & Legislatura &, 256 &, 252 & 1,291 & , 834 & 2,000 \\
\hline \multirow{10}{*}{2} & Intercept & - &, 000 & & & \\
\hline & Estabilidade eleitoral & ,963 &, 014 & 2,619 & 1,211 & 5,663 \\
\hline & Tempo de filiação & ,487 &, 000 & 1,627 & 1,362 & 1,944 \\
\hline & Ideologia deputado &, 080 & 151 & 1,083 &, 971 & 1,208 \\
\hline & Particularismo &, 123 &, 132 & 1,131 &, 964 & 1,327 \\
\hline & Progressismo & 092 &, 300 & 1,096 & ,921 & 1,305 \\
\hline & Religião &, 413 &, 169 & 1,511 &, 839 & 2,720 \\
\hline & Renda &,- 147 &, 285 &, 863 &, 659 & 1,131 \\
\hline & Tradição familiar &,- 044 & ,846 & 957 &, 617 & 1,485 \\
\hline & Legislatura &,- 036 & ,874 &, 965 & 619 & 1,503 \\
\hline
\end{tabular}

${ }^{21} \mathrm{O}$ modelo adotado não permite que o coeficiente de determinação, $\mathrm{R}^{2}$, seja calculado da mesma forma como em uma regressão de tipo linear. Um substituto é o índice de Cox e Snell, que, no caso, atinge 0,427 - o valor 1 significaria que $100 \%$ da variação do fenômeno analisado seria explicada pelas variáveis independentes. 


\begin{tabular}{|c|c|c|c|c|c|c|}
\hline \multirow{10}{*}{3} & Intercept & - &, 000 & & & \\
\hline & Estabilidade eleitoral & 1,275 &, 002 & 3,577 & 1,585 & 8,076 \\
\hline & Tempo de filiação & ,758 &, 000 & 2,134 & 1,757 & 2,592 \\
\hline & I deologia deputado &, 272 &, 000 & 1,312 & 1,161 & 1,483 \\
\hline & Particularismo & ,261 &, 002 & 1,298 & 1,097 & 1,537 \\
\hline & Progressismo & ,216 &, 019 & 1,241 & 1,036 & 1,488 \\
\hline & Religião &, 776 &, 037 & 2,172 & 1,048 & 4,504 \\
\hline & Renda & , 148 & ,334 & 1,159 & , 859 & 1,565 \\
\hline & Tradição familiar &,- 346 &, 149 & ,708 &, 442 & 1,132 \\
\hline & Legislatura &, 459 &, 059 & 1,582 & ,983 & 2,546 \\
\hline \multirow{10}{*}{4} & Intercept & - &, 000 & & & \\
\hline & Estabilidade eleitoral & 2,316 &, 000 & 10,132 & 3,756 & 27,332 \\
\hline & Tempo de filiação & 1,240 &, 000 & 3,457 & 2,492 & 4,794 \\
\hline & Ideologia deputado & , 322 &, 000 & 1,379 & 1,164 & 1,634 \\
\hline & Particularismo &, 438 &, 000 & 1,549 & 1,261 & 1,904 \\
\hline & Progressismo &, 570 &, 000 & 1,767 & 1,407 & 2,220 \\
\hline & Religião & 1,293 &, 102 & 3,643 & ,773 & 17,180 \\
\hline & Renda & 059 &, 769 & 1,061 & ,715 & 1,574 \\
\hline & Tradição familiar &, 232 &, 449 & 1,262 & ,691 & 2,303 \\
\hline & Legislatura &, 462 &, 133 & 1,587 & , 870 & 2,895 \\
\hline
\end{tabular}

Fonte: Banco de dados do projeto "Trajetórias, perfis e padrões de interação de legisladores estaduais em doze unidades da Federação". Obs.: Categoria de referência: 0

As variáveis ideologia, particularismo e progressismo apresentam valores positivos e significativos para as duas categorias mais altas do índice de partidarismo. Deputados classificados na categoria (4) de partidarismo possuem $77 \%$ a mais de chance de ser mais progressistas, $55 \%$ de ser menos particularistas e $38 \%$ de se posicionar à esquerda, sempre que comparados àqueles que se situam na categoria de referência. Quando a comparação leva em conta os entrevistados classificados na categoria (3) de partidarismo, os percentuais diminuem de forma consistente, ainda que de forma menos expressiva no caso da ideologia. Para nenhuma das três variáveis é 
possível dizer que existe diferença significativa entre os deputados situados nos níveis (2), (1) e (0).

As variáveis religião, renda e tradição familiar não apresentam bons resultados quando introduzidas no modelo. As duas últimas não apresentaram significância em nenhuma situação. A primeira revelou um desempenho inconsistente, mantendo-se significativa apenas na comparação entre os deputados situados nas categorias (3) e (1) e a categoria de referência (0). É possível que o pequeno número de evangélicos, somado ao fato de não ter sido possível estabelecer distinções entre o grande número de católicos (separando os carismáticos, por exemplo) tenha influído no resultado.

Finalmente, cabe mencionar a ausência de impacto da variável legislatura. Ao que tudo indica, não há relação entre o nível de partidarismo dos deputados e a legislatura em questão, se 2007-2011 ou 2011-2015.

\section{Conclusão}

No Brasil convivem deputados com trajetória claramente partidária e outros para os quais o partido é um instrumento a ser utilizado de acordo com as circunstâncias. Tendo como base as opiniões de deputados estaduais em 12 estados brasileiros nas legislaturas 2007-2011 e 2011-2015, este artigo procurou explorar essa diferenciação e, dentro de seus limites, explicá-la.

A análise teve início com a elaboração de um índice de partidarismo a partir de seis questões constantes nos questionários aplicados. Com o objetivo de explicar a variação observada no índice, formulou-se um conjunto de hipóteses, cinco das quais puderam ser corroboradas. Os resultados mostram a existência de uma expressiva relação de reforço mútuo entre uma variável de caráter sistêmico, o grau de estabilidade eleitoral e a importância que o deputado confere ao partido. Em outras palavras, ali onde a interação entre os partidos apresenta um padrão mais definido e onde estes jogam um papel de maior relevo na competição política, pode-se dizer que os deputados the atribuem maior importância.

Dentre as variáveis independentes utilizadas e que remetem a características pessoais dos deputados, o tempo de filiação foi a que mostrou maior força explicativa. Ao que tudo indica, quanto mais tempo o legislador fica em seu partido, mais tende a valorizá-lo. Mais ainda, tal variável parece possuir mais força explicativa que ideologia, particularismo e progressismo: estas se mostraram úteis quando a comparação é feita entre os deputados mais partidários, os níveis (4) e (3), e a categoria de referência, mas perdem poder explicativo a partir desse ponto.

Os achados deste artigo confirmam algumas hipóteses de caráter mais geral presentes na literatura e o fazem em melhores condições do que estudo realizado com base apenas na legislatura 2007-2011 (Melo, 2011). A construção de um índice de 
partidarismo contendo cinco categorias representou um teste mais rigoroso do que o realizado anteriormente, quando o índice possuía uma categoria a menos. Cabe destacar que naquela ocasião apenas a variável tempo de filiação mostrou significância na comparação entre todas as categorias do índice de partidarismo. No estudo aqui apresentado, a inclusão de mais uma categoria no índice não impediu que a variável tempo de filiação mantivesse seu impacto, ao passo que a estabilidade eleitoral se fortaleceu. Da mesma maneira, as variáveis ideologia, particularismo e progressismo mantiveram seu desempenho. Por outro lado, o fato de que a introdução da variável legislatura não tenha afetado os resultados do modelo de regressão pode significar que não foi apenas o acréscimo de uma segunda legislatura (a de 2011-2015) que melhorou os resultados obtidos, mas que, essencialmente, os achados do estudo anterior apontavam na direção correta.

Carlos Ranulfo F. Melo - Professor titular do Departamento de Ciência Política da Universidade Federal de Minas Gerais. E-mail: <carlos.ranulfo@yahoo.com.br>.

\section{Referências bibliográficas}

ALMEIDA, L. C. "PPB: origem e trajetória de um partido de direita no Brasil". Dissertação de Mestrado em Ciência Política. USP, DCP, São Paulo, 2004.

AMARAL, O. "Adaptação e resistência: o PT no governo Lula entre 2003 e 2008". Revista Brasileira de Ciência Política, Brasília, vol. 4, p. 105-134, jul.-dez., 2010.

vol. $17, \mathrm{n}^{\circ} 1$, p. $1-44,2011$.

AMES, B. The deadlock of democracy in Brazil. Ann Arbor: University of Michigan Press, 2001.

Ames, B.; Pereira, C.; Rennó, L. Famintos por pork - uma análise da demanda e da oferta por políticas localistas e suas implicações para a representação política. In: POWER, T.; ZUcco, C. O Congresso por ele mesmo: autopercepções da classe política brasileira. Belo Horizonte: Editora UFMG, 2011.

Angelo, V. A.; Villa, M. A. (orgs.). O Partido dos Trabalhadores e a política brasileira. São Carlos: EdUfsCar, 2009.

BeRnABeL, R. "Does the electoral rule matter for political polarization? The case of Brazilian Legislative Chambers". In: Anais do 37 Encontro Anual da Anpocs. Caxambu, 2013.

BoHn, S.; PAIVA, D. "A volatilidade eleitoral nos estados: sistema partidário e democracia no Brasil". Revista de Sociologia e Política, Curitiba, vol. 17, n³3, p. 187-208, 2009. 
CARLOS RANULFO MELO

CAREY, J.; SHUGART, M. "Incentives to cultivate a personal vote: a rank ordering of electoral formulas". Electoral Studies, vol. 12, n 4, p. 417-439, 1995.

CAStRo, M. M. M.; Nunes, F.; AnASTASIA, F. "Determinantes do comportamento particularista de legisladores estaduais brasileiros". Dados - Revista de Ciências Sociais, Rio de Janeiro, vol. 52, $\mathrm{n}^{\circ}$ 4, p. 961-1001, 2009.

FERREIRA, D. PFL x PMDB: marchas e contramarchas. (1982-2000). Goiânia: Editora Alternativa, 2002.

Figueiredo, A.; Limongi, F. Executivo e Legislativo na nova ordem constitucional. Rio de Janeiro: Fundação Getúlio Vargas Editora, 1999.

. "Incentivos eleitorais, partidos e política orçamentária". Dados - Revista de Ciências Sociais, Rio de Janeiro, vol. 45, n², p. 303-344, 2002.

Freston, P. "Protestantismo e política no Brasil: da Constituinte ao impeachment". Tese de Doutorado em Ciências Sociais. Unicamp, 1993.

GuARniERI, F. "A força dos partidos 'fracos'". Dados - Revista de Ciências Sociais, Rio de Janeiro, vol. $54, n^{\circ} 1$, p. 235-258, 2011.

Hagopian, F.; Gervasoni, C.; MoRAES, J. A. "From patronage to program: the emergence of partyoriented legislators in Brazil". Comparative Political Studies, vol. 42, n 3, p. 360-391, 2009.

Hobsbawm, E. A era das revoluções: Europa (1789-1848). Rio de Janeiro: Paz e Terra, 1977.

HUNTER, W. "The normalization of an anomaly: the Workers' Party in Brazil". World Politics, Princeton, $\mathrm{n}^{\circ} 59$, p. 440-475, 2007.

The transformation of the Workers' Party in Brazil, 1989-2009. New York: CUP, 2010.

InÁCIO, M. Engajamento parlamentar no Brasil. In: PoWER, T.; ZuCCo, C. (orgs.). O Congresso por ele mesmo: autopercepções da classe política brasileira. Belo Horizonte: Editora UFMG, 2011.

KECK, M. A lógica da diferença: o Partido dos Trabalhadores na construção da democracia brasileira. São Paulo: Ática, 1991.

KITSCHELT, H. "Linkages between citizens and politicians in democratic politics". Comparative Political Studies, vol. 33, n 6-7, p. 845-879, 2000.

LEMOS, L.; RICCI, P. Individualismo e partidarismo na lógica parlamentar - o antes e o depois das eleições. In: POWER, T.; Zucco, C. (orgs.). O Congresso por ele mesmo: autopercepções da classe política brasileira. Belo Horizonte: Editora UFMG, 2011.

LEÔNCIO, M. R. Partidos políticos, ideologia e composição social. São Paulo: Edusp, 2002.

LINZ, J. Parties in contemporary democracies: problems and paradoxes. In: GUNTHER, R.; RAMONMONTERO, J.; LINZ, J. (orgs.). Political parties: old concepts and new challenges. Oxford: Oxford University Press. 2002.

LIPSET, S.; ROKKAN, S. Party system and voter alignment. Toronto: The Free Press, 1967.

LUnA, J. P.; Altman, D. "Uprooted but Stable: Chilean parties and the concept of party system institutionalization". Latin American Politics and Society, vol. 53, n² 2, p. 1-28, 2011. 
MaINWARING, S. "Políticos, partidos e sistemas eleitorais". Novos Estudos, n²9, p. 34-58, mar. 1991.

Rethinking party systems in the third wave of democratization: the case of Brazil. Stänford: Stanford University Press, 1999.

MAINWARING, S.; SCULLY, T. Building democratic institutions: party systems in Latin America. Stanford: Stanford University Press, 1995.

MAINWARING, S.; TORCAL, M. "Teoria e institucionalização dos sistemas partidários após a terceira onda de democratização". Campinas, Opinião Pública, vol. XI, nº 2, p. 249-286, 2005.

MARENCO dos SANTOS, A. "Sedimentação de lealdades partidárias no Brasil: tendências e descompassos". Revista Brasileira de Ciências Sociais, São Paulo, n 45, p. 69-84, 2001.

"Topografia do Brasil profundo: votos, cargos e alinhamentos nos municípios brasileiros". Opinião Pública, vol. 19, n 1, p. 1-20, 2013.

MeLo, C. R. Retirando as cadeiras do lugar: migração partidária na Câmara dos Deputados (19852002). Belo Horizonte: Editora UFMG, 2004.

. "Individualismo e partidarismo em 12 estados brasileiros". Revista Brasileira de Ciências Sociais, São Paulo, vol. 26, n 75, p. 58-71, 2011.

. "The 2014 elections and the Brazilian party system". Brazilian Political Science Review, vol. $9, n^{\circ} 1$, p. 93-114, 2015.

Melo, C. R.; CÂmarA, R. "Estrutura da competição pela presidência e consolidação do sistema partidário no Brasil", Dados, Rio de Janeiro, vol. 55, n 1, p. 71-117, 2012.

Melo, C. R.; SANTOS, M. "Legisladores, partidos e ideologia: uma análise comparada nos níveis federal e estadual". In: Anais do $7^{\circ}$ Congresso da Alacip. Bogotá, 2013.

MendonçA, A. G.; Velasques, P. Introdução ao protestantismo no Brasil. São Paulo: Loyola, 1990.

MeneguelLo, R. PT: a formação de um partido, 1979-1982. Rio de Janeiro: Paz e Terra, 1989.

Nicolau, J. "A migração partidária na Câmara dos Deputados (1991-1996)". Monitor Público, Rio de Janeiro, n 10, p. 41-45, 1996.

PaneBIAnCo, A. Modelos de partido. Madrid: Alianza Editorial, 1982.

Pieruccl, A. F. "As bases da nova direita". São Paulo, Novos Estudos Cebrap, n 19, p. 26-45, 1987.

"Representantes de Deus em Brasília: a bancada evangélica na Constituinte". Revista Ciências Sociais Hoje, São Paulo, nº 11, p. 104-32, 1989.

Power, T.; Zucco, C. (orgs.). O Congresso por ele mesmo: autopercepções da classe política brasileira. Belo Horizonte, Editora UFMG, 2011.

PRANDI, R. "Perto da magia, longe da política: derivações do encantamento no mundo desencantado". Novos Estudos Cebrap, n³4, 1992.

PRZEWORSKI, A.; SPRAGUe, J. Paper stones: a history of electoral socialism. Chicago: University of Chicago Press, 1986. 
RenNó, L.; Peres, P.; RıCCI, P. "A variação da volatilidade eleitoral no Brasil: um teste com as explicações econômicas, políticas e sociais". Latin American Research Review, vol. 46, 2011.

RIBEIRO, P. F. Dos sindicatos ao governo: a organização nacional do PT de 1980 a 2005 . São Carlos: EdUfscar; São Paulo: Fapesp, 2010.

" "Organização e poder nos partidos brasileiros: uma análise dos estatutos". Revista Brasileira de Ciência Política, n 10, p. 225-265, jan.-abr. 2013.

RIBEIRO, R. L. M. "Decadência longe do poder: refundação e crise do PFL". Dissertação de Mestrado em Ciência Política. USP, Departamento de Ciência Política, 2011.

Rodrigues, L. M. Partidos políticos, ideologia e composição social. São Paulo: Edusp, 2002.

RomA, C. "A institucionalização do PSDB entre 1988 e 1999". Revista Brasileira de Ciências Sociais, vol. 17, n 49 , p. 71-92, 2002.

SAMUELS, D. "Determinantes do voto partidário em sistemas eleitorais centrados no candidato: evidências sobre o Brasil". Dados, Rio de Janeiro, vol. 40, n³ 3, p. 493-535, 1997.

"From socialism to social democracy? The evolution of the Workers' Party in Brazil". Comparative Political Studies, vol. 37, n 9, p. 999-1.024, 2004.

$\overline{2} \overline{0} \overline{0} \overline{8}$.

"A evolução do petismo". Opinião Pública, Campinas, vol. 14, n² 2, p. 302-318, nov.

SAmuels, D.; Zucco, C. "Crafting mass partisanship at the grass roots". British Journal of Political Science, March 2014, p. 1-21. Disponível em:

<http://journals.cambridge.org/abstract_S0007123413000549>. Acesso em: 30 jul. 2014.

SANTOS, F. O Poder Legislativo no presidencialismo de coalizão. Belo Horizonte: Editora UFMG, 2003.

SARTORI, G. Partidos y sistemas de partidos. Madrid: Alianza Editorial, 2005.

ShePSLE, K.; WeINGASt, B. "Political preferences for the pork barrel: a generalization". American Journal of Political Science, vol. 25, $\mathrm{n}^{\circ} 1$, p. 96-111, 1981.

ShugART, M. "Electoral 'efficiency' and the move to mixed-member systems". Electoral Studies, vol. 20, $\mathrm{n}^{\circ} 2$, p. 173-193, 2001.

Singer, A. "Raízes sociais e ideológicas do lulismo". Novos Estudos, n 85, p. 83-102, nov. 2009. $\overline{8} \overline{9}-\overline{1} \overline{1} \overline{1}, \overline{2} 010$.

"A segunda alma do Partido dos Trabalhadores". Novos Estudos, São Paulo, no 88, p.

SPECK, B. "Recursos, partidos e eleições: o papel do financiamento privado, do Fundo Partidário e do horário gratuito na competição política no Brasil". Disponível em: <https://usp-

br.academia.edu/BrunoWilhelmSpeck>. Acesso em: 15 ago. 2014.

Strom, K. "A behavioral theory of competitive political parties". American Journal of Political Science, vol. 34, $n^{\circ} 2$, p. 565-598, 1990.

TARouco, G. Fatores do desenvolvimento do Partido da Frente Liberal. In: PINTO, C.; MARENCO DOS SANTOS, A. (orgs.). Partidos no Cone Sul: novos ângulos de pesquisa. Rio de Janeiro: Fundação Konrad Adenauer, 2002. 
TARouco, G.; MADEIRA, R. "Esquerda e direita no sistema partidário brasileiro: análise de conteúdo de documentos programáticos". Revista Debates, vol. 7, n², p. 93-114, 2013.

VENTURI, G. "PT 30 anos: crescimento e mudanças na preferência partidária", Perseu, n 5, 2010.

VIEIRA, S. M. "O Partido da Social Democracia Brasileira: trajetória e ideologia". Tese de Doutorado em Ciência Política. Universidade Estadual do Rio de Janeiro, 2012.

VINCENT, A. Ideologias políticas modernas. Rio de Janeiro: Jorge Zahar Editor, 1995.

WARE, A. Political parties and party systems. Oxford: Oxford University Press, 1996.

Weber, M. A política como vocação. In: GeRTH, H.; MILLS, C. Max Weber: ensaios de sociologia. Rio de Janeiro: Editora Guanabara, 1982.

Zucco JR., C. A ideologia dos partidos políticos brasileiros. In: Power, T.; Zucco, C. (orgs.). O Congresso por ele mesmo: autopercepções da classe política brasileira. Belo Horizonte: Editora UFMG, 2011.

ZUCCO J R., C.; LAUDERDALE, B. "Distinguishing between influences on Brazilian legislative behavior". Legislative Studies Quarterly, vol. 36, n³, p. 363-396, 2011.

\section{Resumo}

Avaliando vínculos entre partidos e deputados nas Assembleias Legislativas brasileiras

Este artigo parte do suposto de que existe expressiva variação nos vínculos estabelecidos entre legisladores e partidos no Brasil e procura explicá-la a partir de estudo realizado em 12 estados brasileiros. A variação é mensurada com o auxílio de um índice de partidarismo, construído com base em um conjunto de perguntas feitas aos representantes eleitos para as Assembleias Legislativas nas legislaturas 2007-2011 e 2011-2015. A variação encontrada é explicada em dois níveis. O primeiro remete a uma das dimensões da institucionalização dos diversos sistemas partidários estaduais: a estabilidade da competição eleitoral. O segundo remete a uma série de características individuais dos deputados, entre as quais se destaca o tempo de filiação ao partido. I deologia, grau de particularismo no exercício do mandato e grau de progressismo relativamente a temas contemporâneos também apresentam impacto significativo e no sentido esperado sobre a variável dependente - o grau de partidarismo do deputado. As hipóteses aqui apresentadas haviam sido testadas com base em dados relativos à primeira das legislaturas acima. Ao agregar uma segunda legislatura, o presente estudo confirma e dá maior robustez aos resultados encontrados.

Palavras-chave: deputados; partidos; sistemas partidários estaduais; Assembleias Legislativas; ideologia

\section{Abstract}

Evaluating links between parties and deputies in subnational Assemblies in Brazil

This article starts from the assumption that there is significant variation in the relationship between legislators and parties in Brazil and seeks to explain it from a study conducted in twelve states. The variation is measured with the aid of an index of partisanship, built on a set of questions asked the elected representatives to the Legislative Assemblies in 2007-2011 and 2011-2015 legislatures. The variation found is explained on two levels. The first refers to one of the dimensions of 
institutionalization of various state party systems: the stability of electoral competition. The second refers to a series of individual characteristics of the deputies, among which stands out the time to party affiliation. Ideology, degree of particularism in office and degree of progressivism in relation to contemporary issues also have significant impact on the dependent variable - the degree of partisanship. The hypotheses presented here had been tested based on data for the first of the above legislatures. By adding a second term, this study confirms and gives more robust results found.

Keywords: deputies; parties; state party systems; Legislative Assemblies; ideology

Artigo submetido à publicação em setembro de 2014. Versão final aprovada em abril de 2015. 